\title{
Cost Budgeting - A Relevant Instrument for Improving the Performances of a Coal Mine Case Study: Jiului Valley, Romania
}

\author{
lleana-Sorina Rakos ${ }^{1}$ and Mariana Man $^{2}$ \\ ${ }^{1}$ The International Economic Institute, Romanian Academy, Romania \\ ${ }^{2}$ Faculty of Sciences, University of Petroşani, Romania
}

Correspondence should be addressed to: Nihil Sinedeo; nihilsinedeo_68@yahoo.com

Received date: 31 July 2015; Accepted date: 17 November 2015;

Published date: 23 September 2016

Academic Editor: Mardiros Daniela Neonila

Copyright @ 2016. Ileana-Sorina Rakos and Mariana Man . Distributed under Creative Commons CCBY 4.0

\begin{abstract}
In the present article, the authors aim to highlight the importance of turning into monetary units the action program of the mines, as they are currently facing a major problem regarding the maintaining of a balance between their expenses and incomes, because the expenses for the realization of their production highly exceed the level of their incomes coming from the achieved production sale. Starting from the state-of-the-art in the literature on cost-based budgeting in the mines, the present study focuses on the present situation of the coal region known as Jiului Valley. Actually, the authors propose a cost budgeting model - as a means of control for the management - based on the example of the mines of Jiului Valley. The research in the field has been the basis of the applicative study, and it has been able to prove the viability of organizing the management accounting of the Romanian mines, in order to improve their performances. At the end of the present article, the authors express their conclusion regarding the importance of extending the successful implementation of cost budgeting in the companies of the entire country.
\end{abstract}

Keywords: budget, cost budgeting, performance, coal mining industry

\section{Introduction}

Starting from the idea that, at present, management accounting can be the strategic repositioning tool for the companies of the coal mining industry, this paper focuses on the primary energy resources spread throughout the territory of Romania. Thus, we can state in an aware manner that, on the level of Romania, highquality pit coal is still extracted in the microregion of Jiului Valley, and in the region of Oltenia brown coal, a lower quality coal, continues to be extracted in

Cite this Article as: Ileana-Sorina Rakos and Mariana Man (2016), " Cost Budgeting - A Relevant Instrument for Improving the Performances of a Coal Mine Case Study: Jiului Valley, Romania ", Journal of Accounting and Auditing, Vol. 2016 (2016), Article ID 920413, DOI: 10.5171/2016.920413 
quarries, by the National Brown Coal Company of Oltenia. On the level of Jiului Valley, pit coal is still extracted from the underground, from seven mines, out of which three are considered not profitable and are going through closure procedures, the final term being the year 2018, whereas the other four mines are continuing their activity, but in a much slower rhythm compared to the '90s. To support those who would like to see the exploitation of this coal deposit continuing, the authors are trying to demonstrate that the instrument harmonizing and especially increasing the efficiency of the relation between expenses and revenues, in a coal mine, can be the budget. In time, the term "budget" has been defined under different aspects, for example: "a financial plan by which one foresees the share of resources associated to the achievement of a goal by a certain organizational subdivision (...); it represents a set of financial forecasts, realistic and deliberate, translating the company goals" (I.C.Dima and Mariana Man, 2003)[8], and cost budgeting has been defined as a systematic economic practice supposing a formal process of allocation of the financial resources, in order to achieve some goals formulated for the next periods - it is actually a short term forecast of the costs. Budgeting requires the establishment of budgets that should allow the presentation of all the forecasts in the entity, which is why autonomous sub-systems are created, called expense centers or places, concerned with the optimization of the resource use and the obtaining of profit. The expense centre is a part of the company for which expenses can be identified. The profit centre is an extension of this idea on a larger scale, where not only costs, but also profits can be identified. In the management of the mines, it is obligatory to know both the goals to reach and the resources needed to accomplish them. The budgetary process actually constitutes the way of "communication between the top management and mid-level management, regarding the goals proposed and their implementation" (O.Călin, Mariana Man and Monica-Viorica Nedelcu, 2008) [3]. Actually, the way the basic goals and functions - organizing, coordinating, preparing, controlling and assessing the results from a financial-accounting perspective - are established, represents the budget itself - a management tool relevant for the improvement of the mines' activity. Thus, we can state that, to the extent to which the budget is used as a permanent tool in the activity of the coal mines, the company functions will become operable, and they will actually turn into actions of the respective entities. In essence, the budget is a financial plan, elaborated for a certain period of time, which supposes the existance of judicious, continually updated norms on consumptions, prices, manufacturing, overheads etc. and in which four types of factors inter-relate, namely: goals, periods of time, responsibilities and resources. At the same time, the budget is the quantitative expression of an activity plan, elaborated before the period it refers to. Budgets are established on short periods of time, usually one calendar year, with distribution on quarters, months and weeks, and sometimes even up to days, for each job. Starting from these aspects, the questions naturally arising are: At present, do the coal mines possess an efficient budgeting system, providing their managers with real information in due time, to make the best decisions with a positive long-term impact on management accounting? Does the budgeting system implemented in a mine of the coal mining industry - bring advantages?

\section{Literature}

The cost-based budgeting issue in the mines has been studied both by foreign experts - the results being made known through the printed press, by means of the articles published in different data bases, as for example in IDEAS RePEc (13 articles), and by Romanian experts, who have tried, in time, to present the existing situation, from the perspective of the way the financial-accounting balance in the mines is organized, and who, at the same time, have made proposals for the improvement of the mines' performances. Thus, on the international level, one can 
acknowledge the specialized works of several authors with remarkable contributions in this domain, namely: Cokins G. (2009); Horngren, T.C.; Datar, M.S.; Foster, G. (2008); Anwar Shah (2007) $[6,7,12]$. On a national level, one can remark the exceptional contributions, in the sense of the improvement of the budgeting system for the pit coal mined in Jiului Valley. Thus, on a national level, there are a few specialized papers and studies in management accounting, written by outstanding academics who have emphasized the connection between budgeting-planning and strategy (O.Călin, 2000, 2002, 2003; Constanţa Iacob, 1985, $2000,2002,2008,2009,2010$ ), and at the same time there are only few papers that have been the basis of the development and application of several concepts related to the mining activity (Mariana Man, 1998, 2003, 2004, 2006, 2008; C.Cătuţi, 2004; S.C.Teiuşan, 2007). All these papers, dealing with the improvement of the costbased accounting, applied in the mines, have focused on several directions, namely: the study of the organization factors of management accounting, the application principles specific of different cost calculation methods, the adaptation of the accounting plan to the specifics of the mining industry, and the adoption of a new cost budgeting system, adequate for mining. Thus, the importance of the issue of the profitability of the coal mines results mainly from the concerns of different national and international researchers in this sense.

\section{Research methodology}

Starting from the research carried out and the results obtained by the coal mining specialists, the authors have proposed a specific budgeting system for the companies in the Romanian coal mining industry, realizing a case study, in Jiului Valley, Romania, taking the example of the Power Complex of Hunedoara - Mining Division Branch, more precisely, the Coal Mine of Lupeni, which is part of this complex. The methodology used in this research is based, on the one hand, on theoretical research concerning the concepts, theories and regulations in this domain, existing so far in the literature, and their particularization on the level of the coal mining industry and, on the other hand, this study is based on empirical research, through the application of the following methods: observation in the field using sociological methods, analysis of the financial-accounting information using diagnosis methods, based on real cases which highlights a preponderantly inductive approach as general conclusions have been drawn starting from the results obtained on the level of the particular case study of a mine, selected from those included in this branch of the national economy. Throughout this research, the authors have adopted a pragmatic vision and have proposed solutions for the calculation of the production cost of one tonne of coal depending on the practical reality of these companies. The pragmatic vision answers the authors' concern for the identification of a cost-based budgeting system able to lead to the improvement of the performances of the companies in the coal mining industry. Thus, starting from the observation of the fact that although a cost-based accounting specific to coal mining is organized at the central level in the above-mentioned entity, it does not correspond to the informational and decisional needs of the managers of this entity, which is why we have tried to find the answer to the question: Could the cost budgeting system guarantee the improvement of the performances of the Romanian coal mines?

\section{Cost-based budgeting in the coal mines}

During the research in the field, in the mines of Jiului Valley, we found out that, in order to obtain a uniform and correct reporting, the central organism C.E.H. S.A. provides the four mining sub-units under its subordination with counselling, so that they may use a unitary system of documents, necessary for the financial forecast. The coordination of the activity carried out by the mines is achieved by the technical manager and the economic manager, and all the statements submitted by the mining sub-units are analyzed by 
the "own apparatus" of the abovementioned entity, and are presented to its leadership, which, in turn, transmits all the information, as consolidated databases, to the Ministry of Economy, via a special IT programme dedicated to this centralization. One should note that the budgeting model elaborated for the Coal Mine of Lupeni is the same for all the mines in Jiului Valley. Thus, by analyzing the situation present in the region of Jiului Valley, we consider that one of the reasons why the coal mines have recorded losses during the last twenty years is that the income and expense budget has concerns only on the overall level of each mine, paying no attention to cost budgeting on an analytical level, respectively to the elaboration of a budget per each expense category, so that a person of each hierarchic level may be directly in charge with each budget. At the same time, for a unitary building of the budget system on the coal mine level, it is necessary to consider a series of elements, namely: delimiting of the activity sectors and integrating them in the budgetary system; knowing the production capacity of the sector (activity location) budgeted; knowing the activity volume programmed and the way of assessment; knowing the type and dimension of the actual consumption of resources and other indicators specific of each budget; knowing the volume of the sales programmed, taking into account the market prospecting; knowing the costs on primary items and calculation items; calculating the cost per product unit - coal (pit coal); allocating the activity volume planned per destination; selecting the ressource allocation criteria; controlling and analyzing the costs; establishing the responsibility level and limits for budget management; assuring the database for decisions on the hierarchic level; integrating it in the automatic data processing system. In the organization of the budgetary process of such a company, we shall always have in mind its organizational structure, up to the job level, since the elaboration of the budget supposes the drafting of partial budgets of expenses which, after long analyses, are centralized in a general budget of exploitation expenses. In this situation, the responsibility for not exceeding the expenses foreseen by the budget becomes almost the exclusive responsibility of the mine manager and of its chief-accountant. Thus, for the companies in the coal mining industry, profitable would be an analytical cost budgeting, namely a budget on each different hierarchic level, and, for each budget elaborated, there should be a person in charge taking care of the budget and knowing the instructions about the way budgeting in a mine should work, seeing that the budgeting process is a sequential one, with a number of welldefined repetitive steps. Practically, the process of elaboration of the cost-based budget begins by the communication of the details regarding the forecasting policy of the mines and the actions to be taken by the people in charge of the drafting of the partial budgets. The assembling of the budgets leads to the formation of the general budget or, in other words, to the master budget of the companies of the coal mining industry. The general budget comprises all the activity of the mine. The aim of the general budget is grouping/integrating the partial budgets and the plans of different subdivisions of the mine, called particular or functionaloperational and financial budgets. Thus, the general budget represents a working plan coordinated for all the subdivisions and all the types of activities of the mine as a whole or, in other words, the totality of the budgets generating the future operations of all the functional subdivisions of a company of the coal mining industry.

\section{Cost budgeting for a production sector of the mine}

To exemplify such a budgeting in the companies of the coal mining industry, we considered the case in point of the Mine of Lupeni, and within it we considered the production sector " $x$ ". Therefore, the Budget of costs of the production sector " $\mathrm{x}$ " will comprise: the budget of direct material expenses of the production sector; the budget of direct salary expenses and 
salary-related contributions to social insurances and security; the budget of electricity expenses, for operational purposes; the budget of technological fuel expenses; the budget of direct expenses for the amortization of the corporal immobilized assets; the share of indirect expenses of the production sectors; the share of general administrative expenses of the Mine of Lupeni. To understand the structure of a cost budget of the abovementioned centre, we shall represent, in figure no 1, the expense centres, the people in charge with them and the costs controlled.

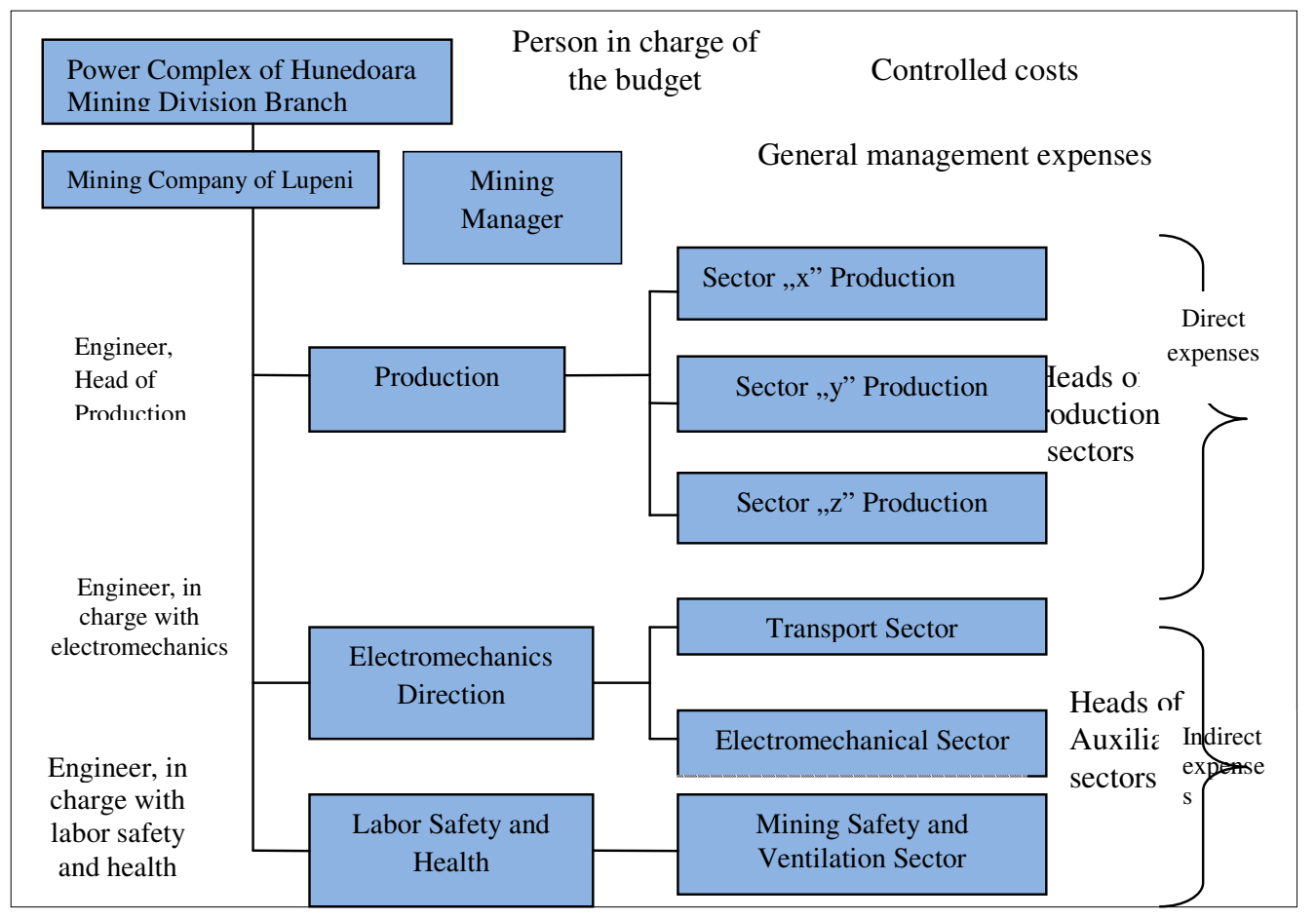

Figure 1: Responsibility distributed on centres

Source: elaborated by authors

On the level of a mine, the Periodical Budgets that can be drafted are: production budget, purchase budget, production cost budget, general management expense budget and sales budget. Considering the interdependence between them, the sales and production budgets represent the budgets determining the parameters of all the other budgets. By the study carried out in the mines of Jiului Valley, the authors noticed that these entities' activity did not trigger sales-related expenses, since the company in charge with the preparation of the coal is subordinated to C.E.H. S.A. Mining Division Branch and has responsibilities regarding the coal preparation and the coal production sales for all the mines in the Jiului Valley. At the same time, in the mine under analysis, we have identified the following responsibility centres: sector " $v$ " - investments; sector " $\mathrm{x}$ " - production; sector " $y$ " - production; sector " $z$ " - production; sector "w" - underground transport; sector " $\mathrm{t}$ " - underground electromechanical sector; sector underground ventilation; sector " $u$ " ground transport; sector "p" - ground electromechanical sector; sector " $r$ " ground ventilation and functional apparatus. The production sectors are 
subdivisions of the mine, well-defined from an administrative perspective, where all the steps of coal mining take place

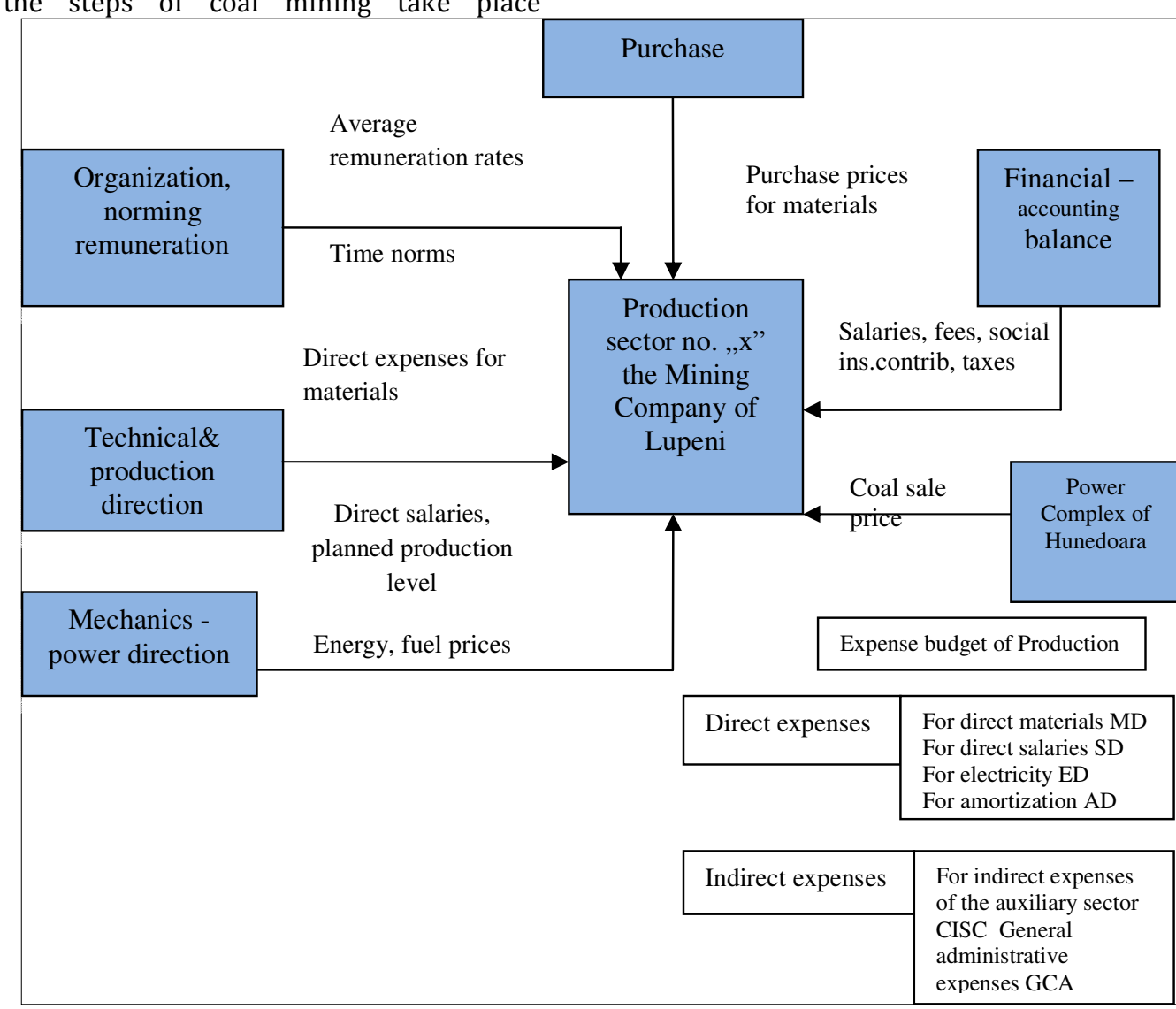

Figure 2: Structure of the cost-based budget on the level of Production Sector " $x$ " of the Mine of Lupeni

Source: Adapted after O. Călin, Mariana Man, Monica-Viorica Nedelcu, Management Accounting,Editura Didactică and Pedagogică, Bucureşti, 2008, p.89

\section{Budgeting direct and indirect expenses in a production sector}

From the perspective of the production features, in the companies of the coal mining industry, cost centres can be developed analytically up to the production and auxiliary sectors level - where a number of successive operations takes place. Thus, the pattern for the cost-based budget (BC) of a coal mine can be according to the technological flows, as in Figure no. 2. 
where: $\mathrm{BC}=$ the budget of costs; $\mathrm{BCD}_{\mathrm{i}}=$ the budget of direct expenses of the production sectors; $\mathrm{BCIP}_{\mathrm{i}}=$ the budget of indirect production expenses of the production sectors; $\mathrm{BCGA}=$ the budget of general administrative expenses on the mine level; $i=\overline{1,3}$, is the number of production sectors; the share of $\mathrm{BD}=$ the share pertaining to the company from the budget of sales. We should mention that, at present, for the selling of the coal

$$
B C D=\sum_{i=1}^{n} B C D_{i}
$$

where: $i=\overline{1, n}$ is the number of production sectors of the mine (the three production sectors of the mine, $i=\overline{1,3}$ ); $\mathrm{BCD}=$ total of the budgets of direct expenses on the level of the three production sectors of the mine; $\mathrm{BCD}_{\mathrm{i}}=$ total of the partial budgets of direct expenses on production, the mines subordinated to the mother company do not have their own budget for sales.

Continuing the analytical study of the budgets of costs, one can notice that the direct expense budget, on the mine level, is made up of the sum of all the budgets related to the direct expenses for each production sector of the mine, which can be mathematically expressed as follows:

(rel.2),

$$
B C D_{i}=\sum_{j=1}^{m} B c d_{j}
$$

the level of a production sector. The budget of a production sector is made up of the sum of all the partial budgets related to the direct expenses needed in a production sector, which can be mathematically expressed using the following relation:

where: $j=\overline{1, m}=$ total of the budgets of partial direct expenses of a production sector. In the present case, there are five partial budgets related to the direct expenses $(j=\overline{1,5})$; $\operatorname{Bcd}_{j}=$ the sum of the partial budgets of direct expenses on the level of a production sector.

\begin{abstract}
The five partial budgets related to the direct expenses, on the level of a production sector, actually make up the direct expense budget on the level of a production sector, which can be mathematically expressed using the following relation:
\end{abstract}

$$
B c d_{j}=B M D_{j}+B E A_{j}+B C T_{j}+B A D_{j}+B S A_{j} \quad \text { (rel. 4), }
$$

where: $\mathrm{BMD}_{\mathrm{j}}=$ the budget for direct material expenses; $B E A_{j}=$ the budget of expenses for energy and water used for operational purposes; $\mathrm{BCT}_{\mathrm{j}}=$ the budget of expenses for technological fuel; $\mathrm{BAD}_{\mathrm{j}}=$ the budget of expenses for direct amortizations; $\mathrm{BSD}_{\mathrm{j}}=$ the budget of expenses for direct salaries and salary-related contributions. In this study, the authors observed that, in the production sector " $\mathrm{x}$ " are employed a number of 162 qualified workers, a foreman specialized in electrical works, a foreman specialized in mechanics, an engineer who is team leader, a sector assistant and a sector head. To the remuneration rates established by the Human Resources Office, the bonuses decided by the management of Lupeni Mine for its employees are added. The hourly rate for the production sector $\mathrm{x}$ is 14.44 RON/hour. 
Thus, for the coal production, the relation

is:

calculating the expenses for direct salaries

$$
S D_{2}=F B_{2}+C A S_{2}+C A S S_{2}+F S_{2}+F N U A S S_{2}+F D A_{2} \quad \text { (rel. 5), }
$$

where: $\mathrm{SD}_{2}$ - budget of expenses for direct salaries for obtaining the coal production in the production sector " $\mathrm{x}$ "; $\mathrm{FB}_{2}$ - gross fund of direct salaries for obtaining the coal production in the production sector " $\mathrm{x}$ "; $\mathrm{CAS}_{2}$ - share of contribution to social insurances (30.8\%); $\mathrm{CASS}_{2}$ - share of contribution to health insurances (5.2\%);
$\mathrm{FS}_{2}$ - share of contribution to unemployment budget $(0.5 \%)$; FNUASS 2 share of contribution to health budget $(0.85 \%) ; \mathrm{FDA}_{2}$ - share of contribution to labor accident budget $(0.638 \%)$. Thus, the direct expense budget for the Coal Mine of Lupeni shall include the budgets in Table 1.

Table 1: Direct expense budget of the Coal Mine of Lupeni - RON -

\begin{tabular}{|c|l|r|r|}
\hline No. & \multicolumn{1}{|c|}{ Name of the direct expense budget } & $\begin{array}{c}\text { Achieved } \\
\text { (cumulated for 7 } \\
\text { months, 2014) }\end{array}$ & $\begin{array}{r}\text { Foreseen for } \\
\text { the year 2015 }\end{array}$ \\
\hline 1. & Direct material expense budget & $\mathbf{4 , 1 0 7 , 5 5 4}$ & $6,661,045$ \\
\hline 2. & $\begin{array}{l}\text { Direct expense budget for water and electricity for } \\
\text { operational purposes }\end{array}$ & $10,870,846$ & $12,880,343$ \\
\hline 3. & Direct expense budget for technological fuel & 127,619 & 286,768 \\
\hline 4. & $\begin{array}{l}\text { Direct expense budget for the amortization of } \\
\text { corporal immobilized assets per tonne of coal }\end{array}$ & 503,100 & $6,406,503$ \\
\hline 5. & $\begin{array}{l}\text { Direct expense budget for salaries and contributions } \\
\text { to social insurances and security }\end{array}$ & $26,766,538$ & $26,309,640$ \\
\hline \multicolumn{2}{|l|}{ Total direct expense budgets on the level of the mine } & $\mathbf{4 2 , 3 7 5 , 6 5 7}$ & $\mathbf{5 2 , 5 4 4 , 2 9 9}$ \\
\hline
\end{tabular}

Source: Processed data, collected from the Coal Mine of Lupeni

In the mines of the coal mining industry, the indirect production expense budgets can be elaborated for each production sector, individually. Their goal is to calibrate - as correctly as possible - the expenses for the auxiliary sectors' activity. According to the authors, the indirect production expenses of a mining entity can be grouped into three large classes, namely: expenses for equipment maintenance and operation (expenses for technical checkups, current repairs and maintenance of the means of transport; expenses for the repairs of the equipment and of the means of transport; amortization of the equipment and of the means of transport etc.); general expenses of the sector; salaries of the management, technical, economic, service and administrative personnel, including contribution to the social insurances and to the unemployment budget; amortization of the buildings and of the other corporal immobilized assets of the production sector; expenses for labor safety); cleaning administrative expenses (expenses for the telephone exchange office; for materials for the maintenance and cleaning of the buildings and of other corporal immobilized assets; expenses for heating, electric lighting etc.). In the drafting of the indirect production expense budget of the production sector " $\mathrm{x}$ " for the year 2015, the determination of the standards for fixed expenses is simple due to their unchanged character despite the modification of the production volume, which allows the use, as a standard, of the previous year level 2014 - with no correction. For the variable overhead charges, the establishment of standards requires the covering of several stages, and after the determination of the standards for each category of expenses of the structure of the overhead charges, one can elaborate the budget. Knowing the situation of the indirect production 
expenses of the production sector " $\mathrm{x}$ " (table 2 ), the authors suggest the distribution of these expenses per each work shift of 6 hours, using the supplementing procedure - the classical form, namely:

Table 2: Indirect production expense budget of the production sector " $x$ " for the year 2015 - RON -

\begin{tabular}{|c|c|c|}
\hline \multirow[b]{2}{*}{ Explanation } & \multicolumn{2}{|c|}{ Expenses (RON) } \\
\hline & $\begin{array}{l}\text { Average of the } \\
\text { last } 7 \text { months } \\
2014\end{array}$ & $\begin{array}{l}\text { Foreseen } \\
\text { (Standard) for } \\
\text { the year } 2015\end{array}$ \\
\hline Activity volume (in tonnes) & 66,708 & $\mathbf{8 1 , 3 1 7}$ \\
\hline I. Fixed expenses: & $8,825,979$ & $10,718,246$ \\
\hline $\begin{array}{l}\text { 1. Salaries for the indirect productive personnel } \\
\text { (TESA), contributions to the social insurances and } \\
\text { to the unemployment budget }\end{array}$ & $6,836,738$ & $8,354,528$ \\
\hline $\begin{array}{l}\text { 2. Amortization of the buildings and of other } \\
\text { corporal immobilized assets }\end{array}$ & 252,259 & 299,747 \\
\hline 3. Tear and wear of the inventory objects & 153,911 & 182,885 \\
\hline 4. Expenses for heating & 35,833 & 42,578 \\
\hline 5. Electricity for lighting & 389 & 463 \\
\hline 6. Expenses for services provided by third parties & $1,403,981$ & $1,668,283$ \\
\hline 7. Other fixed expenses & 142,867 & 169,762 \\
\hline II. Variable expenses: & 473,521 & 562,662 \\
\hline $\begin{array}{l}\text { 1. Expenses for equipment-related technical } \\
\text { checkups, current repairs and maintenance }\end{array}$ & 53,724 & 63,838 \\
\hline 2. Expenses for spare parts & 291,499 & 346,375 \\
\hline 3. Expenses for different materials & 8,437 & 10,025 \\
\hline 4.Expenses for material transport & 73,289 & 87,086 \\
\hline 5. Expenses for fuel & 36,667 & 43,570 \\
\hline 6.Expenses for environmental protection & 9,904 & 11,768 \\
\hline III. Mixed expenses: & 5,371 & 1,857 \\
\hline Labor safety expenses & 5,371 & 1,857 \\
\hline $\begin{array}{l}\text { TOTAL } \\
\end{array}$ & $9,304,870$ & $11,282,765$ \\
\hline
\end{tabular}

Source: processed data, collected from the Coal Mine of Lupeni

As one can notice out of this budget, it results that in the year 2015 for the production sector " $\mathrm{x}$ ", the indirect costs estimated were of $11,282,765$ RON, of which fixed expenses of 10,718,246 RON, variable expenses of 562,662 RON, mixed expenses of 1,857 RON.

The coefficient of indirect expenses of the production sector " $\mathrm{x}$ " has been calculated by reporting the expenses to the distribution base suggested for the economic entity Lupeni Mine - the production volume, since there is a relation of causality between the time needed to obtain coal in a work shift and the expenses to be distributed. For the calculation of the supplementing coefficient, we have used the formula: 


$$
K_{s}=\frac{C H_{r}}{\sum_{j=1}^{n} b j}
$$

where: $K_{s}$ - supplementing coefficient; $\mathrm{CH}_{r}$ - expenses to be distributed; $b_{j}$ - size of the distribution basis; $\mathrm{n}$ - number of work shifts.

$$
R_{j}=b_{j} x k s
$$

Using the data in Table 3, we established the supplementing coefficient for each work shift in the production sector " $\mathrm{x}$ ", for (rel.6),

The share of expenses for a work shift has been calculated using the relation:

(rel.7), the year 2014, according to relation 6, namely:

$$
K_{2}=\frac{11282765}{8530308}=1.3226
$$

The supplementing coefficient has been calculated and it is 1.3226 . It will be applied to each distribution basis which, in the present case, is the direct manpower needed to obtain the production of the production sector " $\mathrm{x}$ ", namely for the work shift I, the direct manpower is of 2,196,980 RON, for the work shift II, the direct manpower is of 2,132,577 RON, for the work shift III, the direct manpower is of $2,089,925$ RON and for the work shift IV, the direct manpower amounts to 2,110,826 RON. Knowing the expenses for the direct manpower for the year 2014, the share of indirect expenses for the obtaining of the coal production is calculated namely: $\mathrm{R}_{\mathrm{I}}=$ $2,196,980 \times 1.3226=2,905,875$ RON.
Similarly, the calculation is done for the other production work shifts. To conclude, the total of $11,282,765$ RON - the indirect costs of the production sector " $\mathrm{x}$ ", in the Mine of Lupeni, distributed on the four work shifts, are, namely: 2,905,875 RON for the work shift I, 2,820,691 RON for the work shift II, 2,764,277 RON for the work shift III, and 2,791,922 RON for the work shift IV. Similarly, this budget is elaborated for the production sectors " $y$ " and " $z$ ", respectively, based on the accounting data regarding the level of these expenses during the last seven months of the year 2014, after which we may elaborate the indirect expense budget on the level of the mine, which is presented in Table no. 3 . 
Table 3: Indirect production expense budget, on the level of the Mine of Lupeni, for the year 2015

\begin{tabular}{|c|c|c|}
\hline \multirow[b]{2}{*}{ Explanation } & \multicolumn{2}{|c|}{ Expenses (RON) } \\
\hline & $\begin{array}{l}\text { Average of the } \\
\text { last } 7 \text { months }\end{array}$ & $\begin{array}{l}\text { Standard year } \\
2015\end{array}$ \\
\hline Activity volume (in tonnes) & 393,886 & 503,100 \\
\hline I. Fixed expenses: & $52,976,936$ & $66,312,696$ \\
\hline $\begin{array}{l}\text { 1. Salaries for the indirect productive personnel (TESA), } \\
\text { contributions to the social insurances and to the } \\
\text { unemployment budget }\end{array}$ & $41,293,819$ & $51,688,615$ \\
\hline $\begin{array}{l}\text { 2. Amortization of the buildings and of other corporal } \\
\text { immobilized assets }\end{array}$ & $1,481,554$ & $1,854,502$ \\
\hline 3. Tear and wear of the inventory objects & 903,945 & $1,131,493$ \\
\hline 4. Expenses for heating & 210,452 & 263,428 \\
\hline 5. Electricity for lighting & 2,287 & 2,863 \\
\hline 6. Expenses for services provided by third parties & $8,245,799$ & $10,321,495$ \\
\hline 7. Other fixed expenses & 839,080 & $1,050,300$ \\
\hline II. Variable expenses: & $2,781,060$ & $3,481,130$ \\
\hline $\begin{array}{l}\text { 1. Expenses for the technical checksup, current repairs and } \\
\text { maintenance of the equipment }\end{array}$ & 315,529 & 394,956 \\
\hline 2. Expenses for the spare parts & $1,712,021$ & $2,142,984$ \\
\hline 3. Expenses for different materials & 49,549 & 62,022 \\
\hline 4. Expenses for the material transport & 430,440 & 538,794 \\
\hline 5. Expenses for fuel & 215,353 & 269,563 \\
\hline 6. Expenses for environmental protection & 58,167 & 72,810 \\
\hline III. Mixed expenses: & 9,180 & 11,491 \\
\hline Labor safety expenses & 9,180 & 11,491 \\
\hline TOTAL & $55,767,176$ & 69,805,317 \\
\hline
\end{tabular}

Source: Processed data, collected from the Coal Mine of Lupeni

As one can notice in the above-mentioned budget, the fixed expenses foreseen for the year 2015 amount to 66,312,696 RON, the variable expenses amount to $3,481,130$ RON, and the mixed expenses have a value of 11,491 RON.

Therefore, the total indirect production expenses of Lupeni Mine amount to $69,805,317$ RON, with an average of $5,817,110 \mathrm{RON} / \mathrm{month}$, for the year 2015, recording a minor increase compared to the average of the 7 months of the year 2014 , which was of 5,576,718 RON/month. The expenses included in the general management expense budget are fixed expenses, since they do not depend on the production volume of the economic entity.

The companies in the coal mining industry include four expense classes, grouped as follows: "general interest expenses, which include the share of $60 \%$, of the Power Complex of Hunedoara - Mining Division Branch (represent the expenses for personnel, considered to be $60 \%$ of the expenses of the Power Complex of Hunedoara, distributed to the Coal Mine of Lupeni), amortization of corporal immobilized assets of general interest; buildings, land, motor vehicle taxes etc.); general expenses regarding the gratuitousness (allocation of coal; 
differences of rates for electricity; heating taxes etc.); internal administrative expenses (office furniture; contracts with third parties, magazines, publications; travels, job relocations, job transfers etc.); maintenance and cleaning expenses (materials for building maintenance and cleaning; water, sewage, sanitation etc.)".

In the present case, the data needed for the elaboration of the general management expense budget for Lupeni Mine is taken from the partial budgets elaborated on the level of each department, individually, adding up all the indirect general interest consumptions. For the elaboration of the present budget, we have taken into consideration the increase of the costs for electricity and thermal energy, the increase of the rates of the transport companies, the increased price of bus transport - to the work place and back, the diminished expenses for the tear and wear of some assets, as a result of their decomissioning etc. Thus, the budget of general administrative expenses drafted for the Mine of Lupeni, is presented in Table 4.

Table 4: Budget of general adminsitrative expenses of the Mine of Lupeni

\begin{tabular}{|c|c|c|}
\hline Explanation & $\begin{array}{c}\text { Preliminary } \\
2014 \\
(\mathrm{RON})\end{array}$ & $\begin{array}{c}\text { Foreseen } 2015 \\
\text { (standard) } \\
\text { (RON) }\end{array}$ \\
\hline I. General interest expenses: & $5,274,036$ & $6,736,385$ \\
\hline Bonus tickets & $1,704,037$ & $2,176,520$ \\
\hline The share of general expenses of the Mining Division & $1,181,053$ & $1,508,527$ \\
\hline Amortization of the general interest assets & 120,778 & 154,266 \\
\hline Taxes for land, company, motor vehicles & 166,622 & 212,822 \\
\hline Taxes for buildings & 244,465 & 312,249 \\
\hline Expenses associated to insurance money & 1,766 & 2,256 \\
\hline $\begin{array}{l}\text { Expenses on taxes for the deliverance of author } \\
\text { certificates }\end{array}$ & 7,886 & 10,073 \\
\hline Expenses on stamp tax & 4,155 & 5,307 \\
\hline Expenses on exploitation tax & 106,947 & 136,600 \\
\hline Royalties & $1,725,242$ & $2,203,605$ \\
\hline Expenses for bank commission & 11,086 & 14,160 \\
\hline II. General expenses on gratuitousness: & $6,461,634$ & $8,253,271$ \\
\hline Allocation of coal & 520,864 & 665,286 \\
\hline Difference of rates for electricity & $1,943,361$ & $2,482,203$ \\
\hline Expenses for lunch & $2,323,985$ & $2,968,364$ \\
\hline Expenses for safety equipment & 269,993 & 344,855 \\
\hline Training of employees & 74,422 & 95,057 \\
\hline Expenses for dispensaries & 368,507 & 470,684 \\
\hline Expenses for the transport to the work place and back & 738,820 & 943,675 \\
\hline Sickness benefits & 16,285 & 20,800 \\
\hline Death grants & 52,930 & 67,606 \\
\hline $\begin{array}{l}\text { Other expenses for social activities (sickness benefits, } \\
\text { Children's Day, Christmas presents) }\end{array}$ & 69,163 & 88,340 \\
\hline Internal-administrative expenses & 41,652 & 53,201 \\
\hline Office furniture & 1,837 & 2,346 \\
\hline
\end{tabular}




\begin{tabular}{|l|r|r|}
\hline Books, magazines, publications and subscriptions & 117 & 150 \\
\hline Expenses for mail delivery & 9,420 & 12,032 \\
\hline Travels, job relocations and transfers in Romania & 30,277 & 38,673 \\
\hline Maintenance and cleaning expenses & $\mathbf{1 , 1 1 5 , 3 5 7}$ & $\mathbf{1 , 4 2 4 , 6 1 5}$ \\
\hline $\begin{array}{l}\text { Electricity for lighting and motor force for administrative } \\
\text { needs }\end{array}$ & 979 & 1,250 \\
\hline Materials for building maintenance and cleaning & 2,819 & 3,600 \\
\hline Patrimony safeguarding & $1,111,560$ & $1,419,765$ \\
\hline Total general administrative expenses & $\mathbf{1 2 , 8 9 2 , 6 7 8}$ & $\mathbf{1 6 , 4 6 7 , 4 7 1}$ \\
\hline
\end{tabular}

\section{Source: Processed data, collected from Hunedoara Power Complex - Mining Division} Branch

$$
\begin{aligned}
& \text { Value of the sector's coal production } \\
& K=\frac{\text { Value of the sector's coal production }}{\text { Value of the mining company's coal production }} \times 100 \text { (rel.8), }
\end{aligned}
$$

where: $\mathrm{K}$ is the distribution index

For the elaboration of the budget of general administrative expenses, we took into account the increase of the rates for electricity and thermal energy, the increase of the salaries as a result of the legal provisions, the increase of the rates practiced by the transport companies, the

$$
\cot a=C G A \times K
$$

where: CGA is the total of the general administrative expenses of the mine, established by the budget.

The general administrative expenses can be distributed on the indirect production expense budget of the production sector " $x$ ", considering the weight of the production obtained by the sector in the total production of the whole mine.

For the auxiliary sections, one can similarly elaborate expense budgets, these expense budgets being taken over from them, during the budgeting stage, by the places benefiting of the services to be carried out. increase of the rates of the rail transport practiced by G.F.R. (The Romanian Railroad Group), the decrease of the expenses for the tear and wear of some inventory objects, as a result of their discommissioning etc. The share of the general administrative expenses corresponding to the production sector is calculated based on the relation:

$$
\text { (rel.9), }
$$

In other words, the expenses of the auxiliary sections are indirectly found in the budgets of the main production sections and of the general management budget of the mine. Knowing the expense budgets elaborated for the production sector " $x$ ", and the share of general administrative expenses of the mine corresponding to the respective sector, taken over from the production expenses triggered by the production activity of the sector, one can elaborate the production cost budget of the Mine of Lupeni, presented in Table 5, according to the relation:

$$
B C_{p}=B M D+B S D+B E D+B C D+B A D+B C I S+B C G E \quad \text { (rel.10), }
$$


where: $\mathrm{BCp}$ - production cost budget; BMD - direct material expense budget; BSD direct salary expense budget (including salary-related contributions); BED expense budget for electricity used for operational purposes; BCD - expense budget for technological fuel; BAD expense budget for the amortization of corporal immobilized assets; BCIS production-related indirect expense budget of the section; BCGE - general management expense budget.

The sales-related expense budget represents the last stage needed to draft the complete cost budget. The sales-related expense budget includes all the expenses triggered by the production sale.

"The sales-related expenses, from the perspective of their components, have a character of complex expenses, being made up of several elements of simple expenses, differing as nature and economic destination".

Thus, the elaboration of the sales-related expense budget can be achieved using the same methodology and procedures as in the case of the elaboration of the other budgets of the entity, respecting the nomenclature of the calculation items that are part of the structure of the sales-related expenses.

The authors suggest that, for the Mine of Lupeni, the distribution basis of the salesrelated expenses should be represented by the quantity of coal sold. The distribution coefficient of the sales-related expenses is calculated based on the following mathematical relation:

$$
K=\frac{\text { Sales related expenses }}{\text { physical production }}
$$

where: $\mathrm{k}$, represents the distribution coefficient of the sales-related expenses:

$$
\text { Cdesf }=k \times \text { physical production }
$$

$$
k=\frac{53231}{2295}=23.194 \quad \text { For the year } 2015
$$

The sales-related expenses distributed on the seven mining units are obtained by the multiplication of the distribution coefficient $\mathbf{K}$ by the physical production realized by each of the seven mining units in turn.
Thus, following the application of this distribution criterion per each of the seven mining units, in Table no. 5, we show the sale-related expenses distributed to them, for the year 2015 . 
Table 5: Situation of the distribution of the sale expenses for the year 2015

\begin{tabular}{|l|c|c|c|c|}
\hline \multicolumn{1}{|c|}{ Unit } & \multicolumn{1}{|c|}{$\begin{array}{c}\text { Actual } \\
\text { production } \\
\text { planned for the } \\
\text { year 2015, in } \\
\text { thousands of } \\
\text { tonnes }\end{array}$} & $\begin{array}{c}\text { Distribution } \\
\text { coefficient for the } \\
\text { year 2015 }\end{array}$ & $\begin{array}{c}\text { Sales-related } \\
\text { expenses } \\
\text { distributed for } \\
\text { the year 2015 } \\
\text { thousands } \\
\text { RON }\end{array}$ & $\begin{array}{c}\text { Distributi } \\
\text { on } \\
\text { percentag } \\
\text { e \% }\end{array}$ \\
\hline $\begin{array}{l}\text { 1. Mining unit of } \\
\text { Lupeni }\end{array}$ & 503.10 & 23.19 & $11,669.07$ & 32.82 \\
\hline $\begin{array}{l}\text { 2. Mining unit of } \\
\text { Lonea }\end{array}$ & 320.00 & 23.19 & $7,422.19$ & 20.87 \\
\hline $\begin{array}{l}\text { 4. Mining unit of } \\
\text { Livezeni }\end{array}$ & 410.00 & 23.19 & $9,509.68$ & 26.74 \\
\hline $\begin{array}{l}\text { 5. Mining unit of } \\
\text { Vulcan }\end{array}$ & 300.00 & 23.19 & $6,958.30$ & 19.57 \\
\hline $\begin{array}{l}\text { Total sales-related } \\
\text { expenses }\end{array}$ & 1,533 & 23,194 & $\mathbf{3 5 , 5 5 9 . 2 4}$ & $\mathbf{1 0 0}$ \\
\hline
\end{tabular}

Source: Processed data, collected from Power Complex of Hunedoara - Mining Division Branch

The budget of sales-related expenses, in Lupeni Mine for the year 2015 can be presented as in Table 6.

Table 6: Sales-related expense budget, in Lupeni Mine for the year 2015

\begin{tabular}{|c|c|c|c|c|c|}
\hline \multirow[b]{2}{*}{ No. } & \multirow[b]{2}{*}{ Calculated items } & \multirow[b]{2}{*}{ Achieved } & \multicolumn{3}{|c|}{ Expenses for the year 2015} \\
\hline & & & $\begin{array}{l}\text { Expenses for } \\
\text { preparation, } \\
\text { cleaning etc. of } \\
\text { the production } \\
\text { delivered to } \\
\text { beneficiaries } \\
\text { (thousands } \\
\text { RONs) }\end{array}$ & $\begin{array}{l}\text { Expenses } \\
\text { for } \\
\text { loading } \\
\text { and } \\
\text { transport } \\
\text { (thousan } \\
\text { ds RONs) }\end{array}$ & $\begin{array}{c}\text { Total } \\
\text { sales- } \\
\text { related } \\
\text { expense } \\
\quad \text { s } \\
\text { (thousan } \\
\text { ds RONs) }\end{array}$ \\
\hline 1 & $\begin{array}{l}\text { Production of the Mine of } \\
\text { Lupeni }\end{array}$ & $88,592.00$ & - & - & $\begin{array}{r}102,129 . \\
00 \\
\end{array}$ \\
\hline 2 & $\begin{array}{l}\text { Expenses for auxiliary } \\
\text { material }\end{array}$ & 43.00 & 7.56 & 43.96 & 51.52 \\
\hline 3 & Expenses for fuel & 0.00 & 0.00 & 0.00 & 0.00 \\
\hline 4 & Expenses for energy & 254.00 & 306.46 & 0.00 & 306.46 \\
\hline 5 & $\begin{array}{lcc}\text { Expenses for } & \text { the } \\
\text { amortization of } & \text { the } \\
\text { immobilized assets } & \\
\end{array}$ & 468.00 & 263.00 & 301.70 & 564.70 \\
\hline 6 & $\begin{array}{l}\text { Expenses for equipment } \\
\text { maintenance and operation }\end{array}$ & 484.00 & 280.00 & 303.55 & 583.55 \\
\hline 7 & $\begin{array}{l}\text { Services provided by } \\
\text { third parties }\end{array}$ & $4,417.00$ & 0.00 & $5,762.30$ & $5,762.30$ \\
\hline 7.1. & $\begin{array}{l}\text { Access of the train convoy } \\
\text { in the mining unit }\end{array}$ & 21.00 & 0.00 & 25.65 & 25.65 \\
\hline 7.2. & $\begin{array}{l}\text { Rail transport of the raw } \\
\text { coal, by GFR (the Romanian } \\
\text { Railroad Group) }\end{array}$ & $3,082.00$ & 0.00 & $4,153.26$ & $4,153.26$ \\
\hline 7.3 . & TOU & 667.00 & 0.00 & 803.21 & 803.21 \\
\hline
\end{tabular}




\begin{tabular}{|c|c|c|c|c|c|}
\hline 7.4. & $\begin{array}{l}\text { Switch of the GFR coal train } \\
\text { carriages }\end{array}$ & 551.00 & 0.00 & 664.66 & 664.66 \\
\hline 7.5 . & Truck transport & 96.00 & 0.00 & 115.53 & 115.53 \\
\hline 8 & Other expenses & 75.00 & 0.00 & 158.93 & 158.93 \\
\hline 9 & Expenses for salaries & 793.00 & 633.00 & 323.22 & 956.22 \\
\hline 10 & $\begin{array}{l}\text { Additional expenses for } \\
\text { salaries }\end{array}$ & 267.00 & 321.81 & 0.00 & 321.81 \\
\hline 11 & $\begin{array}{ll}\text { Other expenses for } \\
\text { personnel }\end{array}$ & 823.00 & 0.00 & 992.39 & 992.39 \\
\hline 12 & $\begin{array}{l}\text { Direct } \quad \text { expenses } \\
(2+3+4+5+6+7+8+9+10+ \\
11)\end{array}$ & $7,624.00$ & $1,811.83$ & $7,886.05$ & $9,697.88$ \\
\hline 13 & Indirect expenses & $1,105.00$ & $1,331.52$ & 0.00 & $1,331.52$ \\
\hline 14 & General expenses & 531.00 & 639.67 & 0.00 & 639.67 \\
\hline 15 & $\begin{array}{l}\text { Total sales-related } \\
\text { expenses }(12+13+14)\end{array}$ & $9,260.00$ & $3,783.02$ & $7,886.05$ & $\begin{array}{r}11,669.0 \\
7 \\
\end{array}$ \\
\hline 16 & $\begin{array}{l}\text { Total product cost per } \\
\text { unit (RON/tonne) }\end{array}$ & 23.50 & 7.5194 & 15.6749 & 23.194 \\
\hline
\end{tabular}

Source: Processed data, collected from Coal Mine of Lupeni

As a result of the presentation of all these issues regarding the budgeting of the sales expenses in the economic entities of the coal mining industry, we suggest that the model for the budget of expenses (BCp) of a coal mine should be based on a relation made up of several terms and which should include the budget of the expenses related to the selling of the product obtained (coalpit coal), namely:

$$
B C_{p}=B M D+B S D+B E D+B A D+B C I S+B C G E+B D \quad(\text { rel.13) }
$$

where: BCp - budget of production cost; BMD - budget of material expenses; BSD budget of direct salary expenses (including salary-related contributions); BED budget of expenses for electricity used for operational purposes; BCD - budget of expenses for technological fuel; BAD budget of expenses for the amortization of corporal immobilized assets; BCIS - budget of indirect production expenses of the section; BCGE - budget of general administrative expenses; BD -budget of sales expenses.

From the perspective of the production particularities, in the economic entities of the coal mining industry, the cost centres can be developed analytically up to the level of the production and of the auxiliary sectors, where a number of successive operations take place.
Mainly, each structure of the economic entity for which the expenses can be delimited and to which a process can be entrusted can constitute a cost centre.

Thus, the cost-based budget of a cost centre includes: the budget of direct material expenses of the production sector; the budget of direct salary expenses and salary-related contributions to social insurances and security; the expense budget for electricity in motor operations; the budget of expenses for technological fuel; the budget of direct expenses for the amortization of corporal immobilized assets; the share of indirect costs of the production sectors, the share of general administrative expenses of the mine, according to Table 7 . 
Table 7: Centralized budget of production expenses of the production sector " $x$ ", for the year 2015

\begin{tabular}{|c|c|c|c|}
\hline No. & Name of the component budgets & M. U. & $\begin{array}{l}\text { Foreseen for the year } \\
\qquad 2015\end{array}$ \\
\hline 1. & Budget of direct material expenses & RON & $1,076,637$ \\
\hline 2. & Budget of expenses for technological fuel & RON & 46,351 \\
\hline 3. & $\begin{array}{l}\text { Budget of expenses for electricity in motor } \\
\text { operations }\end{array}$ & RON & $2,081,854$ \\
\hline 4. & $\begin{array}{l}\text { Budget of direct expenses for the amortization of } \\
\text { corporal immobilized assets }\end{array}$ & RON & $1,269,003$ \\
\hline 5. & $\begin{array}{l}\text { Budgte of direct salary expenses and salary-related } \\
\text { contributions }\end{array}$ & RON & $8,530,308$ \\
\hline 6. & $\begin{array}{l}\text { Budget of indirect (common) production expenses } \\
\text { of the production sector " } \mathrm{x} \text { " }\end{array}$ & RON & $11,282,765$ \\
\hline 7. & $\begin{array}{l}\text { Share of the budget of general administrative } \\
\text { expenses of Lupeni Mine for the production sector } \\
\text { "x" }\end{array}$ & RON & $2,643,949$ \\
\hline 8. & Share of the budget of sales-related expenses & RON & 1,886 \\
\hline & TOTAL & & $26,932,753$ \\
\hline
\end{tabular}

Source: Processed data, collected from the Coal Mine of Lupeni

\section{Master buget of the production costs in a production sector}

Next, by adding up all these partial budgets for the production sectors of a mining entity, one can obtain the Master Budget of the production costs - in the present case, for Lupeni Mine -, shown in Table 8.

\section{Table 8: General budget of the production costs of the Mine of Lupeni}

\begin{tabular}{|c|c|c|c|c|}
\hline No. & Name of the component budgets & M. U. & $\begin{array}{c}\text { Achieved } \\
\text { for the } \\
\text { year } 2014\end{array}$ & $\begin{array}{c}\text { Foreseen } \\
\text { for the year } \\
2015 \\
\end{array}$ \\
\hline 1. & $\begin{array}{l}\text { Physical production (thousands } \\
\text { tonnes) }\end{array}$ & tonnes & 447,787 & 503,100 \\
\hline 2. & Commodity production & thousands RON & 88,592 & 102,129 \\
\hline 3. & Budget of direct material expenses & thousands RON & $5,107.55$ & $6,661.05$ \\
\hline 4. & $\begin{array}{l}\text { Budget of expenses for technological } \\
\text { fuel }\end{array}$ & thousands RON & 127.62 & 286.77 \\
\hline 5. & $\begin{array}{l}\text { Budget of expenses for electricity for } \\
\text { motor operations }\end{array}$ & thousands RON & $11,870.85$ & $12,880.34$ \\
\hline 6. & $\begin{array}{l}\text { Budget for amortization of corporal } \\
\text { immobilized assets }\end{array}$ & thousands RON & $5,338.76$ & $6,406.50$ \\
\hline 7. & $\begin{array}{l}\text { Budget of direct salary expenses and } \\
\text { salary-related contributions }\end{array}$ & thousands RON & $52,103.31$ & $38,545.55$ \\
\hline 8. & $\begin{array}{l}\text { Budget of indirect (common) } \\
\text { production expenses of the section }\end{array}$ & thousands RON & $88,683.91$ & $86,272.79$ \\
\hline 9. & Budget of sales-related expenses & thousands RON & 9,260 & $11,669.07$ \\
\hline & TOTAL & thousands RON & 172,492 & $162,722.07$ \\
\hline
\end{tabular}

Source: Processed data, collected from the Coal Mine of Lupeni 
Therefore, we can say that by putting together the budgets the general budget or, in other words, the master budget of the economic entity of the coal mining industry is obtained. Actually, the General Budget includes all the activity of the mine. The goal of the general budget consists in grouping, adding up the budgets and the plans of the different subdivisions of the mine, called particular or functionaloperational and financial budgets. Thus, the general budget represents a working

$$
B M=B C D+B C I P+B C G A+B D
$$

plan, coordinated for all the subdivisions and types of activities of the economic entity, entirely, or, in other words, the general budget includes the complete budget that generates the future operations of all the functional subdivisions of the economic entity. Finally, adding up all the general budgets for each mine, according to the following relation, we obtain the Master Budget of the Power Complex of Hunedoara - Mining Division Branch, shown in Table 9.

$$
\text { (rel.14), }
$$

BCGA = budget of general administrative expenses; $\mathrm{BD}=$ budget of sales-related expenses where: $\mathrm{BM}=$ represents the Master Budget; $\mathrm{BCD}=$ budget of direct expenses; $\mathrm{BCIP}=$ budget of indirect production expenses;

\author{
expenses
}

Table 9: Budget of the Power Complex of Hunedoara - Mining Division Branch E.M.Lupeni

\begin{tabular}{|c|l|c|c|c|}
\hline No. & $\begin{array}{c}\text { Name of the component budgets for } \\
\text { all the seven mines }\end{array}$ & \multicolumn{1}{|c|}{ M. U. } & $\begin{array}{c}\text { Achieved } \\
\text { for the } \\
\text { year } \\
\mathbf{2 0 1 4}\end{array}$ & $\begin{array}{c}\text { Foreseen } \\
\text { for the } \\
\text { year 2015 }\end{array}$ \\
\hline 1. & Physical production (thousand tonnes) & $\begin{array}{c}\text { thousands of } \\
\text { tonnes }\end{array}$ & 1,812 & 2,268 \\
\hline 2. & Commodity production & thousands RON & 383,489 & 443,483 \\
\hline 3. & $\begin{array}{l}\text { Budget of expenses for direct materials } \\
\text { and technological fuel }\end{array}$ & thousands RON & 46,350 & 59,791 \\
\hline 4. & $\begin{array}{l}\text { Budget of expenses for electricity in } \\
\text { motor operations }\end{array}$ & thousands RON & 32,149 & 43,019 \\
\hline 5. & $\begin{array}{l}\text { Budget of amortization of corporal } \\
\text { immobilized assets }\end{array}$ & thousands RON & 11,910 & 17,304 \\
\hline 6. & $\begin{array}{l}\text { Budget of expenses for direct salaries } \\
\text { and salary-related contributions }\end{array}$ & thousands RON & 196,532 & 277,396 \\
\hline 7. & $\begin{array}{l}\text { Budget of indirect (common) } \\
\text { production expenses of the section }\end{array}$ & thousands RON & 216,737 & 237,214 \\
\hline 8. & $\begin{array}{l}\text { Budget of general administrative } \\
\text { expenses }\end{array}$ & thousands RON & 54,631 & 56,774 \\
\hline 9. & Budget of sales-related expenses & thousands RON & 41,889 & 53,231 \\
\hline & TOTAL & thousands RON & 600,198 & 744,729 \\
\hline
\end{tabular}

Source: Processed data, collected from the Power Complex of Hunedoara - Mining Division Branch

After the elaboration of the budgets, they are transmitted to the persons in charge with their execution. Representing a way of short-term control, and including all the aspects of the activity of the economic entity in a coherent set of numerical forecasts, the budgets must concern the operation, purchase, sales, investments etc.

\section{Elaboration of the budget and calculation of the cost per unit for the product coal - pit coal}

Next, using the grouping of the production expenses per calculation items, we can elaborate, for the Mine of Lupeni, the 
budget of the cost per unit of coal - pit coal product. Using the data recorded in the budgets of partial expenses, we can highlight the budget of the costs per tonne of mined coal. A basic requirement in the application of an efficient strategy in the domain of the production costs is the well thought-out dimensioning of the cost per unit of product. In this respect, on the whole level of the mine, one can elaborate the budget of the cost per unit of product, using the grouping of the production expenses per calculation items.

The substantiation of the budget of the unitary cost per tonne of coal is done based on the data recorded in the budgets of partial expenses, which are part of the master budget of the mine's production cost. Thus, the expenses recorded in the budgets elaborated in the previous subchapter are taken over in the budget of the cost per unit, and re-grouped according to the classification - on calculation items.

Consequently, in Table no. 10 we present the model of budget of the cost per production unit drafted for the coal mine under analysis, i.e. the Mine of Lupeni, for the year 2015 .

Table 10: Budget of the cost per unit of mined coal for the year 2014 in the Mine of Lupeni

\begin{tabular}{|c|c|c|c|c|}
\hline \multirow[t]{2}{*}{ Specification } & \multicolumn{2}{|c|}{$\begin{array}{l}\text { Achieved for the year } \\
\qquad 2014\end{array}$} & \multicolumn{2}{|c|}{$\begin{array}{l}\text { Foreseen for the year } \\
\qquad 2015\end{array}$} \\
\hline & $\begin{array}{c}\text { thousands } \\
\text { RON }\end{array}$ & RON/tonne & $\begin{array}{c}\text { thousands } \\
\text { RON }\end{array}$ & $\begin{array}{l}\text { RON/ } \\
\text { tonne }\end{array}$ \\
\hline $\begin{array}{l}\text { Physical production (thousands of } \\
\text { tonnes) }\end{array}$ & 447.787 & - & 503.100 & 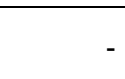 \\
\hline Commodity production & 88,592 & 197.84 & 102,129 & 202.999 \\
\hline Raw materials and direct materials & $5,107.55$ & 11.41 & $6,661.05$ & 13.24 \\
\hline Technological fuel & 127.62 & 0.28 & 286.77 & 0.57 \\
\hline Electricity & $11,870.85$ & 26.51 & $12,880.34$ & 25.60 \\
\hline $\begin{array}{l}\text { Amortization of corporal immobilized } \\
\text { assets }\end{array}$ & $5,338.76$ & 11.92 & $6,406.50$ & 12.73 \\
\hline Direct salaries & $39,785.01$ & 88.85 & $29,001.60$ & 57.65 \\
\hline $\begin{array}{l}\text { Contributions to social insurances and } \\
\text { security, pertaining to direct salaries }\end{array}$ & $12,318.30$ & 27.51 & $9,543.95$ & 18.97 \\
\hline TOTAL DIRECT EXPENSES & $74,548.09$ & 166.48 & $64,780.21$ & 128.76 \\
\hline Indirect expenses, of which: & $88,683.91$ & 198.05 & $86,272.79$ & 171.48 \\
\hline Fixed expenses & $62,976.94$ & 140.64 & $66,312.70$ & 131.81 \\
\hline Variable expenses & $2,805.12$ & 6.26 & $3,481.13$ & 6.92 \\
\hline Mixed expenses & 9.18 & 0.02 & 11.49 & 0.02 \\
\hline General expenses of the section & $22,892.68$ & 51.12 & $16,467.47$ & 32.73 \\
\hline Sales-related expenses & $9,260.00$ & 20.68 & $11,669.07$ & 23.19 \\
\hline TOTAL COST & $172,492.00$ & 385.21 & $162,722.07$ & 323.44 \\
\hline
\end{tabular}

Source: Processed data, collected from Coal Mine of Lupeni

As one can see in this table, on the level of the budgetary year 2015, the standard production volume of the coal mine is foreseen to be 503,100 tonnes, the commodity production is foreseen to be102,129 thousands RON, and the price per unit according to our calculations is of $202.99 \mathrm{RON} /$ tonne. Thus, we can calculate the cost per unit for a tonne of mined coal, using the following relation: 
Calculation of the cost per unit $(\mathrm{Cu})$

$$
B_{C u}=\frac{\sum_{i=1}^{n} C h_{i}}{Q}
$$

$\sum^{n} \quad \mathrm{~B}_{\mathrm{Cu}}$ is the budgeted cost per unit, $\sum C h_{i}$ is the sum of the total expenses of the three sectors, $Q$ is the physical production (tonnes of mined coal).

Replacing the symbols by numbers in relation no. 15, we obtain the budgeted cost per unit, pertaining to a tonne of coal:

$$
C u=\frac{162722.07}{503.100}=323.44 \text { RON / tonne }
$$

Replacing, in the denominator, the total expenses by the expenses per primary expense items, we obtain the cost per unit

for each expense item, in turn. These dat are presented in table 11 .

Table 11: Budget of cost per unit for the product "mined coal" for the year 2015, at the

\begin{tabular}{|c|c|c|c|c|}
\hline \multirow[t]{2}{*}{ No. } & \multirow{2}{*}{$\begin{array}{l}\text { Name of the component budgets } \\
\text { for all the seven mines }\end{array}$} & \multirow{2}{*}{ M. U. } & \multicolumn{2}{|c|}{ Year 2015} \\
\hline & & & Foreseen & RON/tonne \\
\hline 1. & $\begin{array}{l}\text { Physical production (thousands of } \\
\text { tonnes) }\end{array}$ & $\begin{array}{l}\text { thousands } \\
\text { tonnes }\end{array}$ & 2,268 & - \\
\hline 2. & Commodity production & thousands RON & 443,483 & 195.54 \\
\hline 3. & $\begin{array}{l}\text { Budget of expenses for direct } \\
\text { materials and technological fuel }\end{array}$ & thousands RON & 59,791 & 26.36 \\
\hline 4. & $\begin{array}{l}\text { Budget of expenses for electricity in } \\
\text { motor operations }\end{array}$ & thousands RON & 43,019 & 18.97 \\
\hline 5 & $\begin{array}{l}\text { Budget for the amortization of } \\
\text { corporal immobilized assets }\end{array}$ & thousands RON & 17,304 & 7.63 \\
\hline 6 & $\begin{array}{l}\text { Budget of expenses for direct } \\
\text { salaries and salary-related } \\
\text { contributions }\end{array}$ & thousands RON & 277,396 & 122.31 \\
\hline 7 & $\begin{array}{l}\text { Budget of Indirect (common) } \\
\text { production expenses of the section }\end{array}$ & thousands RON & 237,214 & 104.59 \\
\hline 8 & $\begin{array}{l}\text { Budget of general administrative } \\
\text { expenses }\end{array}$ & thousands RON & 56,774 & 25.03 \\
\hline 9 & Budget of sales-related expenses & thousands RON & 53,231 & 23.47 \\
\hline & TOTAL & thousands RON & 744,729 & 328.36 \\
\hline
\end{tabular}
Power Complex of Hunedoara - Mining Division Branch

Source: Processed data, collected from the Power Complex of Hunedoara - Mining Division Branch

If the management by budgets is applied by the leadership of the companies in the coal mining industry, the analysis of the deviations is an objective necessity, since the deviations need to be justified according to their nature: nominal, positive, negative or exceptional deviations. These centralizing budgets of the production expenses triggered by the activity in each production sector need to be related to the responsibility area of the head-of-sector, which will facilitate the monitoring, the control and the analysis of the way the costs are charged within the limits 
established by the budgets. The Power Complex of Hunedoara - Mining Division Branch will centralize the budgets from all the mines subordinated to it, elaborating the proposition of budget, which needs to be presented to the Administrative Board for validation. The success of budgeting in these companies will depend completely on the qualities and concern of the employees regarding the accomplishment of the budget goals.

\section{Conclusions}

Based on the data presented, one can see that cost budgeting in the companies of the coal mining industry - Jiului Valley, can be a relevant tool for the improvement of their performances. The fact that these companies are divided into several autonomous companies, each of them with autonomous budgets, has triggered the creation of expense centers or profit centres whose targets consisted in reducing the costs and increasing the profit. Each coal face can be dealt with as a profit centre, and, at the same time, each production sector of each mine and each mine of the Power Complex of Hunedoara will be, in their turn, profit centres, with results that can be established precisely, quite easily and at every moment, a thing that is particularly important for the management of the mine. By forecasting the budgets of expenses in the short or in the long run, one can also realize the strategies that the company can adopt, in the short or in the long run. By the model proposed, the annual forecasts will have an acceptable analytical basis, the monthly forecasts shall be correlated to the annual ones, the forecast of the production for the following month will take into account the conditions of the coal face. At the same time, by practicing a management by budgets, one can also realize an adequate budgetary control, which allows the detection of errors or deviations from standard costs, giving therefore the possibility of identifying, analyzing them and correcting the negative situations recorded. The obtaining of real costs is the key that guarantees the efficiency of the decisions made by the leadership of the companies in the coal mining industry. Moreover, we consider that budgeting in the coal mines is important for the success of the activity on a branch level, determining the whole managerial team to collaborate for the realization of a thorough analysis of the performance at all the management levels, which should lead, in time, to the viability of these economic entities of the national economy and not to their closure, as it is happening at present. From here, it results in the undeniable importance of budgeting, by means of which the global performance of the mine and of the whole Power Complex of Hunedoara is assured. Following the study undertaken at the Mine of Lupeni, we conclude that the companies of the coal mining industry do not sufficiently use the possibilities of tracking their economicfinancial efficiency, on coal faces - offered by the development of the network of internal budgets, on types of structure corresponding to the general and specific organization that describe a whole set and then detail the internal processes, beginning by the inputs of resources and continuing by the outputs concretized in results. Practically, cost bugeting is the solution identified to what is being practiced today regarding the financial forecast in the mines of Jiului Valley. Thus, the budgeting process proposed supposes much more elaborate developments of details in the short run. We consider that, in order to benefit of all its qualities of lever of the economic-financial management, the budget of a mine should be developed into a network of budgets, should go down to the level of each responsibility center to determine the activity places having a a negative influence on the results of the company.

\section{Acknoledgement}

This paper has been financially supported within the project entitled "Horizon 2020 Doctoral and Postdoctoral Studies: Promoting the National Interest through Excellence, Competitiveness and Responsibility in the Field of Romanian Fundamental and Applied Economic Research", contract number 
POSDRU/159/1.5/S/140106. This project is cofunded by the European Social Fund through Sectoral Operational Programme for "Human Resources Development 20072013. Investing in people!"

\section{References}

1. Anwar Shaw (2007), Budgeting and Budgetary Institutions, The International Bank for Reconstruction and Development/The World Bank;

2. Bouquin, H. (2003), Comptabilité de gestion, Economic Publishing House, Paris;

3. Burlaud, A. (2000), Control de gestiune, Editura Coresi, București;

4. Călin, O.; Man, M.; Nedelcu, M. (2008), Contabilitate managerială, Editura Didactică şi Pedagogică, Bucureşti;

5. Cucui, I. (2008), Costurile şi importanța lor în controlul gestiunii firmei, Editura Arves, Craiova;

6. Cokins,G.(2009), Performance Management: Integrating Strategy Execution, Methodologies, Risk and Analytics, John Wiley \& Sons Inc., Hoboken, New Jersey;

7. Diaconu, P. (2002), Contabilitate managerială, Editura Economicã, Bucureşti;
8. Dima, I.C., Man, M. (1999), Managementul activităţii industriale, Editura Academiei Române, Bucureşti;

9. Dima, I.C., Mariana Man, Control de gestiune, Editura AGIR, București, 2003, pag.61;

10.Ebbeken, K.; Possler, L.; Ristea, M. (2000), Calculaţia şi managementul costurilor, Editura Teora, Bucureşti;

11. Horomnea, E. (2001), Tratat de contabilitate, Sedcom Libris Publishing House, Iaşi;

12.Horngren, T.C.; Datar, M.S.; Foster, G. (2008), Contabilitatea costurilor, o abordare managerială, Ediţia a XI-a, Editura Sedcom Libris, Iaşi;

13.Jan F.Jacobs, (2013), Budgeting and Budgetary Control;

14.Iacob, C.; Ionescu, I. (2003), Contabilitate de gestiune, Editura Sitech, Craiova;

15. Măcriş, M., (2010), Bazele economiei, Editura Universitas, Petroşani;

16.Yves de Rougé, Karine Cerrada, (2008), Méthodes d'analyses des coûts et contrôle budgétaire, Pearson Education. 